\title{
Prevalence and Factors Associated with Parental Traditional Medicine Use for Children in Motta Town, Amhara Regional State, Ethiopia, 2014
}

Tenaw Gualu Melesse ${ }^{* 1}$, Yohannes Ayalew ${ }^{2}$, Girma Alem Getie ${ }^{1}$, Haymanot Zeleke Mitiku ${ }^{1}$ and Girmay Tsegaye ${ }^{1}$

${ }^{1}$ Department of Nursing, College of Health Sciences, Debremarkos University,Debremarkos, Ethiopia

${ }^{2}$ Departments of Nursing and Midwifery, School of Allied Health Sciences, College of Health Science, Addis Ababa University, Addis Ababa, Ethiopia

"Corresponding author: Tenaw Gualu Melesse, Department of Nursing, College of Health Sciences, Debremarkos University Debremarkos, Ethiopia, Tel: +252 91384 14 96; E-mail: tenawgualu@yahoo.com

Rec date: Oct 27, 2014; Acc date: Nov 27, 2014; Pub date: Nov 29, 2014

Copyright: (c) 2014 Melesse TG, et al. This is an open-access article distributed under the terms of the Creative Commons Attribution License, which permits unrestricted use, distribution, and reproduction in any medium, provided the original author and source are credited.

\begin{abstract}
Background: Traditional medicine is the ancient and culture bound medical practice which existed in human societies before the application of modern science to health. Around $80 \%$ of Ethiopians relies on traditional medicines. Although some traditional medical practices in children are useful and contributing positively and need to be strengthen, some are harmful from the perspective of health. In Ethiopia, studies conducted so far are very limited and focused on adults. As a result, this study was conducted to assess the prevalence and factors associated with parental traditional medicine practice for children.
\end{abstract}

Objective: The aim of this study was to assess prevalence and factors associated with parental traditional medicine use for children in Motta Town.

Methods: Community based cross-sectional study design was used. Data was collected using structured interviewer administered questionnaire. The study was conducted among 381 households selected using systematic random sampling method. Both descriptive and inferential statistics were used to present the data. Odds ratio, binary and multiple logistic regression were used to assess the association between dependent and independent variables.

Result: It was found that $88.2 \%$ of parents had used either forms of traditional medicine for their children. The top therapies used were herbs $(66.9 \%)$, religious therapies $(52.8 \%)$, massage $(22.8 \%)$, bone settler $(21.8 \%)$ and traditional birth attendants (13.1\%). Female parents, low educational level, accessibility of traditional medicine, low price and perceived effectiveness were significantly associated with parental traditional medicine use for children.

Conclusion and recommendation: There was high parental traditional medicine practice for children in this study. Female parents, low educational status, easily accessibility, cheap in price and perceived effectiveness were significant predictors. The integration of traditional medicine as part of modern medicine and controlling mechanism should be strengthen. Community education and further research on its efficacy and safety should also be done.

Keywords: Traditional medicine; Parent; Children; Motta; Ethiopia

\section{Abbreviations:}

AOR: Adjusted Odds Ratio; ASD: Autism Spectrum Disorder; CAM: Complementary and Alternative Medicine; CI: Confidence Interval; COR: Crude Odds Ratio; HEW's: Health Extension Workers; MDG: Millennium Development Goal; SPSS: Statistical Package for Social science; TM: Traditional Medicine; USA: United States of America; WHO: World Health Organization.

\section{Introduction}

World Health Organization (WHO) defines traditional medicine as diverse health practices, approaches, knowledge and beliefs incorporating plant, animal, and/or mineral based medicines, spiritual therapies, manual techniques and exercises applied singularly or in combination to maintain well-being, prevent illness as well as to diagnose and treat illness [1].
In Asia and Latin America, for example, population continues to use traditional medicine. In China, traditional medicine accounts for around $40 \%$ of all health care delivered. On the other hand, up to $80 \%$ of people in Africa use traditional medicine to meet their health care needs [1]. Ethiopian people have been using traditional medicine since time immemorial. Around $80 \%$ of its population relies on traditional medicines [2].

There are many factors that push people to rely on traditional, complementary and alternative medicine all over the world in recent times. Because it is easily accessible, more affordable, closely corresponds to the patients ideology and less paternalistic than modern medicine, the appeal of traditional, complementary and alternative medicine increases [3].

Irrational use of medicine is a major problem worldwide. It is estimated that more than half of all medicines are prescribed, dispensed or sold inappropriately and that half of all patients fail to take them correctly. This contributes to enormous health and economic impacts both at a personal and national level [4]. As a result, 
Page 2 of 6

pediatric use of complementary and alternative medicine (CAM) therapies raises legal as well as clinical concerns [5].

Children are dependent on their parents. They cannot fight for their health rights. And some traditional practices like harmful traditional health practices were found to be killing practices for children. These practices are violating the children's health rights and hindering the country from achieving millennium development goal (MDG 4) [6].

Even though the use of traditional complementary and alternative therapies in children has recently shown explosive growth, there is little scientific evidence of benefit, a need for better regulatory oversight, and continuing gaps in the knowledge and attitudes of pediatric health professionals [7].

In Ethiopia, studies conducted so far are very limited and focused on adult traditional medical practices. The use of traditional medicine has not been widely studied among children. Therefore, this crosssectional study was conducted to assess prevalence and predictors of parental traditional medicine use for children. So determining the rational of increased childhood traditional medicine utilization has paramount importance and it will fill the gaps in this regard.

\section{Objectives}

General objective: To assess the prevalence and factors associated with parental traditional medicine use for children in Motta town, Amhara Regional State, Ethiopia, 2014.

Specific objective: To determine the prevalence of parental traditional medicine use for children for the last twelve months. To identify factors associated with parental traditional medicine use for children

\section{Methods and Materials}

Study area: The study was conducted in Motta town which is found in East Gojjam Zone, Amhara region of Ethiopia.

Study design: Community based cross-sectional study design was used.

\section{Study period: The data was collected from March to April/2014.}

Source population: All parents having under eighteen years of age children who live in Motta Town.

Study population: All randomly selected parents having under eighteen years of old children who fulfill the inclusion criteria were included.

Inclusion criteria: Parents who were permanent residents at least for six months have under eighteen years old children who live with them at least for six months. Available at the time of data collection were included.

Exclusion criteria: Parents who were seriously ill or unable to give the required information during data collection period were excluded.

Sample size: A total of 381 households were included in this study.

Sampling procedure: Study populations (parents having under eighteen years old children) were selected using systematic sampling technique.

\section{Instrument and measurement}

The data collection tool was a structured interviewer administered questionnaires. Either the father or mother of the children was interviewed. But priority was given for the mother because mothers are close to their children than fathers. Structured interviewer administered questionnaires adapted and modified from previous researches done on similar topics [8-11] and was translated in to the local language (Amharic). The questionnaire consists of five parts. The first part consisted of predisposing factors. Under this part, the questionnaire dealt about parental socio demographic characteristics and value - believe systems. The second part comprised of prevalence of utilization of TM. The third part of the questionnaire comprised enabling factors. The fourth part of the questionnaire was about need factors and the last section was regarding health care experience.

\section{Personnel}

Eight health extension workers (HEWs) were involved in the data collection.

\section{Data quality control}

Data collectors (HEWs) were trained on how to interview and record and assigned out of their respective kebeles to minimize information bias. In order to assess the validity and reliability of the instrument, clarity of the questions and respondent reaction to the question and interviewer, pre-test was done in another kebeles at 5\% of actual respondents. After the pre-test unclear questions were collected and interviewers adjusted themselves as required. But the data from the pre-test was not included in the analysis. When the head of household (mother/father) was unavailable during data collection period, repeated trials until three times were done. During the data collection time, regular monitoring and supervision of the overall activity was done by the supervisors and principal investigator to ensure the quality of data.

\section{Data processing and analysis}

The data was cleaned, coded and entered in Epi data version 3.1 and transferred to SPSS version 20.0 for analysis. Finally, descriptive and inferential statistics were used to summarize the data.

\section{Variables}

Dependent variable: Parental traditional medicine use for children

Independent variables: Predisposing Factors such as socio demographic characteristics of parents (age, sex, religion, marital status, economic level, education, family size and resident). Enabling Factors (cost, accessibility and source of referral). Need Factors (conditions such as promotion, prevention and treatment, type of illness, perception of illness and parental rating of child health). Health Care Experience (parental CAM use, dissatisfaction with modern medicine, efficacy of CAM, fear of side effect of modern medicine and cost of modern medicine) (Table 1).

\section{Ethical consideration}

Ethical approval and clearance to conduct this research were obtained from Research and Ethical Review Committee of Department of Nursing and Midwifery, School of Allied Health Sciences, College of Health Science, Addis Ababa University. Permission to conduct the 
Citation: Melesse TG, Ayalew Y, Getie GA, Mitiku HZ, Tsegaye G (2015) Prevalence and Factors Associated with Parental Traditional Medicine Use for Children in Motta Town, Amhara Regional State, Ethiopia, 2014. Altern Integr Med 4: 179.doi:10.4172/2327-5162.1000179

Page 3 of 6

study was also requested from Motta Town Administration. Voluntariness was asked and signed on the consent form. The aim of the study was explained and participants were informed about confidentiality of the data.

\section{Result}

\section{Prevalence of traditional medicine utilization for children}

Among the total 381 participants of this study, 336(88.2\%) had used at least one form of traditional medicine for their children in the last 12 months. Among this $79.8 \%$ were females and 8.4 were males. Herbal medicine were most commonly practiced 255(66.9\%) followed by religious/prayer practice 201(52.8\%), massage $87(22.8 \%)$, bone settler $83(21.8 \%)$, tooth extractors $38(10.8 \%)$ and $16(4.2 \%)$ have mentioned as they used other forms of traditional medicine named: Yehareg ressa, Salehu dress and Yebuda medhanit in their culture

\begin{tabular}{|c|c|c|c|}
\hline Variable & & Frequency $(\mathrm{N})$ & Percentage(\%) \\
\hline \multirow[t]{2}{*}{ Sex } & Male & 41 & 10.8 \\
\hline & Female & 340 & 89.2 \\
\hline \multirow[t]{4}{*}{ Age (years) } & $\leq 25$ & 63 & 16.5 \\
\hline & $26-35$ & 179 & 47 \\
\hline & $36-45$ & 108 & 28.3 \\
\hline & $>45$ & 31 & 8.1 \\
\hline \multirow[t]{3}{*}{ Religious affiliation } & Orthodox & 228 & 59.8 \\
\hline & Muslim & 145 & 38.1 \\
\hline & Others* & 8 & 2.1 \\
\hline \multirow[t]{4}{*}{ Marital status } & Single & 18 & 4.7 \\
\hline & Married & 233 & 61.2 \\
\hline & Divorced & 86 & 22.6 \\
\hline & Widowed & 44 & 11.5 \\
\hline \multirow[t]{4}{*}{ Educational status } & $\begin{array}{l}\text { Unable to read and } \\
\text { write }\end{array}$ & 192 & 50.4 \\
\hline & Read and write & 103 & 27 \\
\hline & Primary school (1-8) & 28 & 7.3 \\
\hline & High school (9-12) & 32 & 8.4 \\
\hline \multirow[t]{2}{*}{ Residence } & Urban & 252 & 66.1 \\
\hline & Sub urban & 129 & 33.9 \\
\hline \multirow{3}{*}{$\begin{array}{l}\text { Number of children } \\
(<18 \text { years })\end{array}$} & Less than three & 271 & 71.1 \\
\hline & Three- four & 104 & 27.3 \\
\hline & Greater than four & 6 & 1.6 \\
\hline \multirow{3}{*}{$\begin{array}{l}\text { Monthly income } \\
\text { (Ethiopian birr) }\end{array}$} & $<500$ & 180 & 47.2 \\
\hline & $500-850$ & 114 & 29.9 \\
\hline & $851-1500$ & 56 & 14.7 \\
\hline
\end{tabular}

\section{Factors associated with traditional medicine practice}

Respondents were asked to list what their reasons were to use traditional medicine for their child/children. Among these (47.5\%) mentioned accessibility, (34.4\%) cheap in price, (31.5\%) having low income, (15\%) referred by someone else and $4.7 \%$ mentioned lack of time for emergency problems and cultural acceptability of traditional medicines. Study participants have used traditional medicine to treat different health problems (Figure 1).

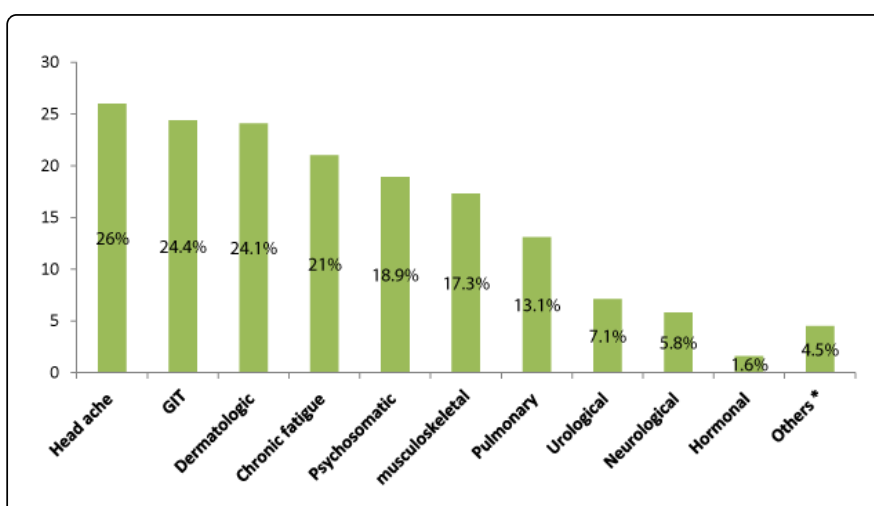

Figure 1: Frequency of children symptoms treated by parental traditional medicine in Motta town, Amhara region, North West Ethiopia, April 2014. (In the last 12 months) Note: ${ }^{*}$ Eye problems, Ear problems.

Study participants were asked about their reasons for applying traditional than modern medicine. From this, nearly half of respondents $(47.2 \%)$ used because as it was effective when selected correctly, (37.8\%) difficulty in accessing health care facility $(20.2 \%)$ fear of using drugs and side effect, $(11.3 \%)$ satisfaction with traditional medicine, (6\%) dissatisfaction with modern medicine, (3.9\%) less efficacy of modern medicine and (4.5\%) mentioned non-curable diseases with modern medicine and cultural acceptability (Table 2).

\begin{tabular}{|l|l|l|l|}
\hline \multicolumn{2}{|l|}{ Variables } & $\begin{array}{l}\text { Frequency } \\
\text { (N) }\end{array}$ & $\begin{array}{l}\text { Percentage } \\
(\%)\end{array}$ \\
\hline $\begin{array}{l}\text { Have you ever used TM for } \\
\text { yourself in the last } 12 \\
\text { months? }\end{array}$ & Yes & 316 & 82.9 \\
\cline { 2 - 4 } & No & 65 & 17.1 \\
\hline Who had used CAM? & Mother only & 169 & 44.4 \\
\cline { 2 - 4 } & Father only & 95 & 24,9 \\
\cline { 2 - 4 } & Both & 117 & 30.7 \\
\hline \multirow{4}{*}{$\begin{array}{l}\text { How do you indicate the level } \\
\text { of TM efficacy? }\end{array}$} & Very poor & 6 & 1.6 \\
\cline { 2 - 4 } & Poor & 87 & 22.8 \\
\cline { 2 - 4 } & Fair & 52 & 13.6 \\
\cline { 2 - 4 } & Very good & 170 & 44.6 \\
\hline
\end{tabular}


Citation: Melesse TG, Ayalew Y, Getie GA, Mitiku HZ, Tsegaye G (2015) Prevalence and Factors Associated with Parental Traditional Medicine Use for Children in Motta Town, Amhara Regional State, Ethiopia, 2014. Altern Integr Med 4: 179.doi:10.4172/2327-5162.1000179

Page 4 of 6

\begin{tabular}{|l|l|l|l|}
\hline & Excellent & 66 & 17.3 \\
\hline $\begin{array}{l}\text { How do you indicate your } \\
\text { level of satisfaction after TM } \\
\text { use? }\end{array}$ & $\begin{array}{l}\text { Completely } \\
\text { dissatisfied }\end{array}$ & 9 & 2.4 \\
\cline { 2 - 4 } & $\begin{array}{l}\text { Somewhat } \\
\text { dissatisfied }\end{array}$ & 79 & 20.7 \\
\cline { 2 - 4 } & $\begin{array}{l}\text { Neither satisfied } \\
\text { nor dissatisfied }\end{array}$ & 15 & 3.9 \\
\cline { 2 - 4 } & $\begin{array}{l}\text { Somewhat } \\
\text { satisfied }\end{array}$ & 154 & 40.4 \\
\cline { 2 - 4 } & $\begin{array}{l}\text { Completely } \\
\text { satisfied }\end{array}$ & 124 & 32.5 \\
\hline
\end{tabular}

\begin{tabular}{|l|l|l|l|}
\hline \multirow{2}{*}{$\begin{array}{l}\text { Over all how do you rank the } \\
\text { quality of your experience } \\
\text { with modern healthcare }\end{array}$} & Very bad & 5 & 1.3 \\
\cline { 2 - 4 } systems? & Bad & 15 & 3.9 \\
\cline { 2 - 4 } & Good & 82 & 21.5 \\
\cline { 2 - 4 } & Very good & 111 & 29.1 \\
\cline { 2 - 4 } & Extremely good & 168 & 44.1 \\
\hline
\end{tabular}

Table 2: Health care experience of participants in Motta town, Amhara region, North West Ethiopia, April 2014 (In the last 12 months, $\mathrm{N}=381$ ).

\begin{tabular}{|c|c|c|c|c|c|}
\hline \multicolumn{2}{|l|}{ Variables } & \multicolumn{4}{|c|}{ Parental TM use for children } \\
\hline & & \multirow{2}{*}{$\begin{array}{l}\text { Yes } \\
32(8.4)\end{array}$} & \multirow{2}{*}{$\begin{array}{l}\text { No } \\
9(2.4)\end{array}$} & \multirow{2}{*}{$\begin{array}{l}\text { COR }(95 \% \mathrm{Cl}) \\
1\end{array}$} & \multirow{2}{*}{$\begin{array}{l}\text { AOR }(95 \% \mathrm{Cl}) \\
1\end{array}$} \\
\hline Sex & Male & & & & \\
\hline & Female & $304(79.8)$ & $36(9.4)$ & $2.38(1.05-5.37)$ & $2.66(1.11-6.40)^{*}$ \\
\hline \multirow[t]{5}{*}{ Educational status } & Illiterate & $174(45.7)$ & $18(4.7)$ & $3.56(1.32-9.62)$ & $3.10(1.10-8.84)^{*}$ \\
\hline & Read and write & $92(24.1)$ & $11(2.9)$ & $3.08(1.06-8.97)$ & $3.45(1.12-0.61)^{*}$ \\
\hline & Primary(1-8) & $25(6.6)$ & $3(0.8)$ & $3.07(0.70-3.46)$ & $4.80(1.02-2.67)^{*}$ \\
\hline & High school & $26(6.8)$ & $6(1.6)$ & $1.6(0.46-5.52)$ & $0.97(0.26-3.66)$ \\
\hline & Above high school & $19(5.0)$ & $7(1.8)$ & 1 & 1 \\
\hline \multirow[t]{4}{*}{ Monthly income } & $<500$ birr & $162(42.5)$ & $18(4.7)$ & $3.68(1.47-9.20)$ & \\
\hline & $500-850$ birr & 102(26.8) & $12(3.4)$ & $3.48(1.31-9.26)$ & \\
\hline & $851-1500$ birr & $50(13.1)$ & $6(1.6)$ & $3.41(1.08-0.75)$ & \\
\hline & $>1500$ birr & $22(5.8)$ & $9(2.4)$ & 1 & \\
\hline \multirow[t]{2}{*}{ Accessibility of TM } & Yes & $168(44.1)$ & $13(3.4)$ & $2.46(1.25-4.86)$ & $2.97(1.42-6.18)^{\star}$ \\
\hline & No & 168(44.1) & $32(8.4)$ & 1 & 1 \\
\hline \multirow[t]{2}{*}{ Cheap in price } & Yes & $122(32.0)$ & $9(2.4)$ & $2.28(1.06-4.89)$ & $2.41(1.10-5.43)^{\star}$ \\
\hline & No & $214(56.2)$ & $36(9.4)$ & 1 & 1 \\
\hline \multirow[t]{2}{*}{ Parental TM use } & Yes & $284(74.5)$ & $32(8.4)$ & $2.22(1.10-4.51)$ & \\
\hline & No & $52(13.6)$ & $13(3.4)$ & 1 & \\
\hline \multirow[t]{2}{*}{ Effectiveness of TM } & Yes & $167(43.8)$ & $13(3.4)$ & $2.43(1.23-4.80)$ & $2.48(1.21-5.08)^{\star}$ \\
\hline & No & $169(44.4)$ & $32(8.4)$ & 1 & 1 \\
\hline \multirow{2}{*}{$\begin{array}{l}\text { Difficulty in accessing } \\
\text { modern medicine and } \\
\text { cost }\end{array}$} & Yes & $135(35.4)$ & $9(2.4)$ & $2.69(1.25-5.76)$ & \\
\hline & No & 201(55.1) & $36(9.4)$ & 1 & \\
\hline
\end{tabular}

Table 3: Bivariate and multivariate logistic regression analysis of factors associated Parental TM use for children in Motta Town, Amhara Region, North West Ethiopia, April $2014(\mathrm{~N}=381)$.

\section{Discussion}

In this cross-sectional study, the prevalence of parental traditional medicine use for children was $88.2 \%$. It was higher when compared to a research done in Kuala Lumpur, Malaysia, 84.5\% [12] and Southern Arizona, 64\% [13]. The difference might be from methodological and cultural differences between the studies. The previous studies were conducted at health care setting and this study was community based. 
In a health care setting study, people could be said that they have experience with modern health care system, so the prevalence of traditional medicine use for children might be decreased (Table 3).

In this study, the most commonly used TM therapies were herbal medicine $(66.9 \%)$, religious therapy $(52.8 \%)$, massage $(22.8 \%)$ and bone settler $(21.8 \%)$. This study is in line with a research done in Southern Arizona where spiritual therapies were most commonly used [13]. This might be due to in Ethiopia also most of the people are religious and religious therapies are given priority. However, the study was in contrary in most cases with the study conducted in EasternHarargie district of Oromya region, Ethiopia, where uvulectomy, tonsillectomy, cauterization, milk tooth extraction, spiritual healing and herbal medicine were the most commonly used therapies [6]. The difference could be from the study population; in this study, participants were parents having under eighteen years old children and in previous study participants were parents having under five years old children. And uvulectomy, tonsillectomy, cauterization, milk tooth extraction are commonly practiced among under five children not for older children. In addition, because these are invasive procedures now a days the practices are somewhat decreased.

Some of the socio-demographic characteristics were significantly associated with parental traditional medicine use for children. Adjusting for other factors, sex of the parent was significantly associated with parental traditional medicine practice. Females were 2.66 times more likely to use traditional for their children than males. This was in congruent with studies done in India, Ireland and USA where female gender was an independent predictive factor of CAM use [14-16]. This might be; because female parents spent most of their time with their children than male parents and they are near to their children. But a study done in Addis Ababa, showed there is no significance difference between sexes [2]. The difference might be from the methodology of the study. In a study done at Addis Ababa, the study participants were traditional healers and patients who attend traditional clinic for themselves.

Another factor that affects parental traditional medicine practice was educational level. Parental educational status was significantly associated with parental TM use for children in this study. Illiterate parents were 3.10 times more likely to practice traditional medicine for their children than parents above high school educated. This is not in line with previous studies done in Calabria and Finland where parents who use traditional medicine for their children were more educated [17-20]. This could because; this study was community based and most of the participants were illiterate.

Resources found within the family and the communities were another pushing factors for traditional medicine practice [21]. In this study, accessibility of traditional medicine was significantly associated with parental use for children. Those parents who perceived traditional medicine as it is being easily accessible were 2.97 times more likely to use traditional medicine for their children when compared to those who perceived as it isn't accessible. This is in line with another study, where accessibility and acceptance of treatments were predictive of parental CAM use for ASD [19].

From the total participants $131(34.4 \%)$ perceived traditional medicine as it is cheap. Adjusting for other factors, parents who recognized traditional medicine as it is being cheap enough were 2.4 times more likely to practice for their children than those who didn't perceive as it is cheap. It was lower than a study done in Ghana where $58.6 \%$ users of traditional health care services claimed that traditional medical services are "cheap" [22]. This may be due to the socioeconomic and market differences between participants in Ghana and Ethiopia.

Perceived effectiveness of traditional medicine was another factor significantly related with parental traditional medicine utilization. In this study, 167 (43.8\%) of participants perceived traditional medicine as effective when selected correctly and had used for their children. Adjusting for other factors, those who perceived traditional medicine as effective were 2.48 times to use for their children than those who perceived as it is not accessible. This was in agreement with a study done among Calabrian children, where perception of the efficacy of traditional medicine was high in all interviewed [17].

Although parental use of traditional medicine for themselves was significantly associated with childhood traditional medicine practice in previous studies $[13,16,19,22]$. In this study, there wasn't significant difference between parents who had used for themselves and those who hadn't used it previously. Probably this could be because child and maternal health service have received government attention currently and health education has been given at large to the parents regarding children's health.

\section{Conclusion}

There was high parental traditional medicine practice for children in this study $(88.2 \%)$. This indicates the contribution of traditional medicines to the public health is significant. The study showed that for the majority of parents traditional medicines were among the options to promote, prevent and treat their children's health/health problems. The most commonly used traditional medicine therapies were herbal medicines, religious practice, massage, bone settlers, and tooth extraction in order. Female parents, low educational status of parents, easily accessibility of traditional medicines, being cheap in price and perceived effectiveness of traditional medicines were predictors for parents to use traditional medicine for their children.

\section{Recommendation}

1. Since perceived efficacy is predictor for traditional medicine use, safety and efficacy of traditional medicine should be studied further.

2. Controlling mechanism should be set regarding traditional healers and traditional medicine accessibility.

3. Education, support and counseling should be given to community at large and particularly to the women regarding traditional medicines.

4. Further national wide research (quantitative and qualitative) including children's characteristics should be conducted.

\section{Acknowledgement}

First and for most thanks to the Almighty GOD who is our power and strength. Our gratitude extends to Motta town administration, data collectors and study participants. It is our admiration to Addis Ababa University and Debre Markos University for their financial support to conduct this study 
Citation: Melesse TG, Ayalew Y, Getie GA, Mitiku HZ, Tsegaye G (2015) Prevalence and Factors Associated with Parental Traditional Medicine Use for Children in Motta Town, Amhara Regional State, Ethiopia, 2014. Altern Integr Med 4: 179.doi:10.4172/2327-5162.1000179

Page 6 of 6

\section{Authors contribution}

The authors have contributed their unreserved effort throughout this study in data collection, preparation of the manuscript and approval of the final manuscript.

\section{Conflict of interest}

We declare that we have no competing interests

\section{References}

1. WHO (2002) WHO traditional medicine strategy 2002-2005. World Health Organization Geneva

2. Birhan W, Giday M, Teklehaymanot T (2011) The contribution of traditional healers' clinics to public health care system in Addis Ababa, Ethiopia: a cross-sectional study. J Ethnobiol Ethnomed 7: 39.

3. Santé Omdl (2001) Legal Status of Traditional Medicine and Complementary-alternative Medicine: A Worldwide Review: Worlds health organization WHO WHO Medicines Strategy

4. Cohen MH, Kemper KJ (2005) Complementary therapies in pediatrics: a legal perspective. Pediatrics 115: 774-780.

5. Sadik EA GT, Mengistu B (2013) Aspects of Common Traditional Medical Practices Applied for Under Five Children in Ethiopia, Oromia Region, Eastern-Harargie District, Dadar Woreda, 2011 G.C. J Community Med Health Educ. 3: 237.

6. Woolf AD, Gardiner P (2010) Use of complementary and alternative therapies in children. Clin Pharmacol Ther 87: 155-157.

7. Ellison CG, Bradshaw M, Roberts CA (2012) Spiritual and religious identities predict the use of complementary and alternative medicine among US adults. Prev Med 54: 9-12.

8. Oshikoya KA, Senbanjo IO, Njokanma OF, Soipe A (2008) Use of complementary and alternative medicines for children with chronic health conditions in Lagos, Nigeria. BMC Complement Altern Med 8: 66.

9. Curlin FA, Rasinski KA, Kaptchuk TJ, Emanuel EJ, Miller FG, et al. (2009) Religion, clinicians, and the integration of complementary and alternative medicines. J Altern Complement Med 15: 987-994.

10. Kim JH, Nam CM, Kim MY, Lee DC (2012) The use of complementary and alternative medicine (CAM) in children: a telephone-based survey in Korea. BMC Complement Altern Med 12: 46.
11. Hamidah A, Rustam ZA, Tamil AM, Zarina LA, Zulkifli ZS, et al. (2009) Jamal R. Prevalence and parental perceptions of complementary and alternative medicine use by children with cancer in a multi-ethnic Southeast Asian population. Pediatric blood \& cancer 52: 70-74.

12. Sanders H, Davis MF, Duncan B, Meaney FJ, Haynes J, et al. (2003) Use of complementary and alternative medical therapies among children with special health care needs in southern Arizona. Pediatrics 111: 584-587.

13. Pankaj G, Prateek S, Saurabh R (2011) Determinants of self-medication practices in an urban slum community. Asian J Pharm Clin Res 4: 54-57.

14. Chang KH, Brodie R, Choong MA, Sweeney KJ, Kerin MJ (2011) Complementary and alternative medicine use in oncology: a questionnaire survey of patients and health care professionals. BMC Cancer 11: 196.

15. Yussman SM, Ryan SA, Auinger P, Weitzman M (2004) Visits to complementary and alternative medicine providers by children and adolescents in the United States. Ambul Pediatr 4: 429-435.

16. Dolceamore TR, Altomare F, Zurlo F, Miniero R (2012) Use of alternative-complementary-medicine (CAM) in Calabrian children. Ital J Pediatr 38: 70

17. Vlieger AM, van de Putte EM, Hoeksma H (2006) [The use of complementary and alternative medicine in children at a general paediatric clinic and parental reasons for use]. Ned Tijdschr Geneeskd 150: 625-630.

18. Hall SE (2013) Factors Affecting Parents' Decisions to Treat Their Children with Autism Spectrum Disorder with Complementary and Alternative Treatments

19. Hämeen-Anttila KP, Niskala UR, Siponen SM, Ahonen RS (2011) The use of complementary and alternative medicine products in preceding two days among Finnish parents - a population survey. BMC Complement Altern Med 11: 107.

20. Gyasi RM, Mensah CM, Adjei PO-W, Agyemang S (2011) Public perceptions of the role of traditional medicine in the health care delivery system in Ghana. Global Journal of Health Science 3: 40.

21. Hurvitz EA, Leonard C, Ayyangar R, Nelson VS (2003) Complementary and alternative medicine use in families of children with cerebral palsy. Dev Med Child Neurol 45: 364-370.

22. Adams D, Dagenais S, Clifford T, Baydala L, King WJ, et al. (2013) Complementary and alternative medicine use by pediatric specialty outpatients. Pediatrics 131: 225-232. 